\title{
Laadukkaita kasveja viherrakentamiseen
}

\author{
Juhanoja Sirkka \\ MTT Kasvintuotannon tutkimus, puutarhatuotanto, Toivonlinnantie 518, 21500 Piikkiö, \\ sirkka.juhanoja@mtt.fi
}

\section{Tiivistelmä}

Viherrakentamisen kasvien laadun parantamiseksi alkoi 1980-luvulla hankkeita, joissa etsittiin olemassa olevista istutuksista tuotantoa varten kestäviä, terveitä ja koristearvoltaan hyviä pensaskantoja suvuista ja lajeista, joissa oli laatuvaihtelua ja nimistöllistä kirjavuutta. MTT toteutti kaksi aiheeseen liittyvää tutkimusta vuosina 1989-2003.

Keskas-kantavalintakokeet vuosina 1989-2000 olivat jatkoa Helsingin yliopiston Keskashankkeelle. Siinä kerättiin rekisteriin yli 700 kasvikantaa. Kantavalintakokeet tehtiin vertailevina kenttäkokeina pellolla viidellä MTT:n tutkimuspaikalla eri ilmastovyöhykkeillä Piikkiöstä Rovaniemelle. Kokeissa oli mukana kasveja suvuista Forsythia, Hydrangea, Lonicera, Philadelphus, Rosa, Spiraea, Syringa ja Viburnum. Kukin kenttäkoe kesti viisi vuotta, ja kasveista arvioitiin talvenkestävyyttä, terveyttä ja koriste- ja käyttöarvo-ominaisuuksia. Aitous varmistettiin.

Puuvartisten maanpeitekasvien menestymistä ja soveltumista eri käyttötarkoituksiin selvitettiin vuosina 1998-2003 tutkimuksessa, jossa menetelmänä olivat kenttäkokeiden lisäksi käyttökokeet. MTT:ssä Piikkiössä ja Ruukissa kasvit olivat pellolla kenttäkokeessa, josta saatiin perustietoa ominaisuuksista ja menestymisestä. Tärkeässä osassa tutkimuksessa olivat viherrakentamiskohteissa tehdyt käyttökokeet. Nämä toteutettiin Helsingin, Kuopion, Lahden, Mikkelin, Tampereen ja Turun kaupunkien viheryksiköiden kanssa. 13 suvun kasveja istutettiin puistoihin ja liikennealueille, joissa testattiin kasvien kestävyyttä ja peittokykyä. Tulosten perusteella laadittiin suositukset 12 lajin sopivimmalle taimikoolle ja istutusten perustamistavalle. Suositeltavat lajit ovat suvuista Dasiphora, Diervilla, Prunus, Ribes, Rubus, Salix, Spiraea ja Stephanandra.

Yhtenäisissä pelto-olosuhteissa tehtävät vertailevat kenttäkokeet antavat luotettavaa tietoa kasvikantojen ulkonäköön ja menestymiseen perustuvista eroista. Käytännön tarvetta varten kokeet on syytä tehdä 2-3 menestymisalueella. Kantavertailukokeet saataisiin tehdyksi pienemmällä taimimäärällä ja pinta-alalla, mikäli kannat karsittaisiin DNA-tunnistuksen avulla. Käyttökokeista saadaan kasvien käyttöarvosta tietoa, jota pelkistä kenttäkokeista ei saada.

Tutkimusten tuloksena markkinoitavan kasviaineiston tunnukseksi rekisteröitiin vuonna 1997 FinE ${ }^{\circledR}$-tavaramerkki, joka voidaan myöntää Suomessa tutkitulle, eri ilmastoalueilla menestyvälle viherrakentamisen kasviaineistolle ja kotipuutarhoihin soveltuville suomalaisille marja- ja hedelmälajikkeille. Kasvit saatetaan tuotantoon MTT Laukaan tutkimus- ja valiotaimiaseman kautta. FinE ${ }^{\circledR}$-tavaramerkki on tähän mennessä myönnetty 19 koristepensaalle ja 20 marja- tai hedelmälajikkeelle.

Asiasanat: kantavertailu, käyttökoe, lajikkeet, maanpeitekasvit, puut, pensaat, talvenkestävyys, valinta, viherrakentaminen 


\section{Johdanto}

Viherrakentamisen kasvimateriaalin laadun parantamiseksi Suomessa käynnistyi 1980-luvulla kolme hanketta, joissa kerättiin ja rekisteröitiin olemassa olevista istutuksista kestäviä, terveitä ja kauniita koristepensaita tuotantoa varten. Pohjois-Suomessa Lapin taimitarhatuotannon kehittämisprojekti ja Pohjois-Suomen viherrakentamisen käyttökasvien kehittämisprojekti vastasivat työstä, Oulun läänin eteläpuoleisella alueella Keskas-projekti hoiti tehtävän (Alanko \& Tegel 1989). Pelkästään Keskasprojektissa rekisteröitiin viiden vuoden aikana yli 700 puu- ja pensaskantaa. Osa aineistosta oli valmista suoraan lisäykseen ja käyttöön, mutta suuri osa oli alkuperältään kirjavaa, suuresti muuntelevaa ja nimistöltään sekalaista. Näin ollen kasviaineiston testaaminen vertailevissa kenttäkokeissa osoittautui välttämättömäksi ennen kasvien lisäykseen saattamista.

Viherrakentamisen ongelma-alueille, liikennealueille, luiskiin, suojaistutuksiin ja luonnonmukaisille viheralueille soveltuvista kasveista kaivattiin tietoa, ja Keskas-raportissa esitettiin jo näkemys käyttökokeiden tarpeellisuudesta. Viherrakentamisessa uusien tai vähän käytettyjen lajien soveltuvuus ongelmakohteisiin oli aiheellista selvittää todellisiin viherrakentamiskohteisiin perustettavissa käyttökokeissa (Alanko \& Tegel 1989).

Maa- ja elintarviketalouden tutkimuskeskuksessa, MTT, toteutettiin Keskas-kantavalintakokeet vuosina 1989-2000. Tutkimuksen tavoitteena oli Keskas-rekisteriin merkittyjä kasvikantoja peltoolosuhteissa vertailemalla saada esiin kantojen väliset erot, tarkistaa kantojen aitous ja nimetä parhaat kannat selkeällä yksiselitteisellä kantanimellä. Parhaat kannat saatettiin tuotantoon. Päämääränä oli myös kehittää menetelmä kantojen arviointia ja valintaa varten. Lisäksi haluttiin luoda tutkitulle suomalaiselle kasviaineistolle oma tunnus (Juhanoja ym. 2001).

MTT:ssa toteutettiin vuosina 1998-2003 toinenkin hanke, jossa hyödynnettiin Keskasrekisteriin merkittyä kasviaineistoa. Tämä hanke oli nimeltään "Puuvartisten maanpeitekasvien menestyminen ja soveltuminen eri käyttökohteisiin". Siinä tavoitteena oli löytää hyviä eri kohteisiin soveltuvia maanpeitekasveja, laajentaa tarjolla olevaa kasvivalikoimaa ja laatia suositukset parhaiden lajien taimikoolle, istutustiheydelle ja kasvuston perustamistavalle julkisilla alueilla (Vehkalahti \& Juhanoja 2001, Juhanoja 2005).

Tutkimuksessa parhaiksi osoittautuneen kasvimateriaalin esiin saamiseksi muissa Pohjoismaissa on otettu käyttöön tavaramerkki: Ruotsissa tutkitut kasvit saavat E-planta -merkinnän, jonka myös norjalaiset ovat ottaneet käyttöön, Tanskassa puolestaan on rekisteröity Dafo ${ }^{\circledR}$ tavaramerkki tutkitun tanskalaisen taimiaineiston tunnukseksi. Englannissa on käytetty merkintää LA- ja MA- vuosilukuun liitettynä. Suomessa kantavalintakokeiden tulosten esiin tuomiseksi haluttiin myös kehittää tunnus. Päädyttiin rekisteröimään FinE ${ }^{\circledR}$-tavaramerkki.

\section{Aineisto ja menetelmät \\ Keskas-kantavalintakokeet}

Keskas-kantavalintakokeissa aineisto muodostui Keskas-rekisteröintivaiheessa talteen otetuista lupaavista kasveista sekä taimistojen, kasvitieteellisten puutarhojen ja arboretumien kokoelmien samojen sukujen kiinnostavista kasvikannoista. Mukana olivat suvut Forsythia, Hydrangea, Lonicera, Philadelphus, Rosa, Spiraea, Syringa ja Viburnum. Aineisto koostui lajien ja lajikkeiden eri klooneista. Osa klooneista oli risteymiä, etenkin kuusamien, jasmikkeiden ja syreenien suvuissa. Kasvit lisättiin Piikkiössä ruohomaisista pistokkaista, ja taimet istutettiin kenttäkokeisiin syksyllä vuoden päästä lisäyksestä. Koemenetelmänä olivat vertailevat kenttäkokeet pellolla. Koepaikkoja oli viisi: Piikkiö (menestymisvyöhyke 1B), Pälkäne (2), Ruukki (5), Sotkamo (5/6) ja Rovaniemi (6/7), ja kukin koe kesti vähintään viisi vuotta.

Jokainen pensas havainnoitiin yksilöllisesti. Havaintoja tehtiin taimien talvenkestävyydestä, terveydestä, kasvutavasta ja koristearvosta kasvukauden eri aikoina. Lisäksi merkittiin muistiin fenologiset tapahtumat: lehtien puhkeaminen, kukkiminen, ruskaantuminen ja lehtien variseminen. Vuosittain havainnoitiin noin 30 ominaisuutta. Osa ominaisuuksista oli mitattavia, jatkuvia, osa luokittelevia. Koejärjestelyt ja havainnot on kuvattu yksityiskohtaisesti julkaisuissa (Juhanoja ym. 1998, Juhanoja ym. 2001).

Kantojen keskinäinen paremmuus arvioitiin neljällä tavalla, joista kaksi oli ei-tilastollista ja kaksi tilastollista menetelmää. Lisäksi aineistoa tarkasteltiin diskriminanttianalyysin tulosten 
perusteella. Valintaa tehtäessä vertailtiin eri menetelmien tuloksia. Käytetyt menetelmät ja niiden tulokset on julkaistu tieteellisessä sarjassa (Juhanoja ym. 1998).

\section{Puuvartiset maanpeitekasvit}

Kasvimateriaali muodostui Keskas-rekisteriin merkityistä kasveista sekä kasvitieteellisten puutarhojen ja taimistojen matalista lehtipensaskannoista. Taimet lisättiin ruohomaisista pistokkaista pääosin MTT:ssa, mutta käyttökokeisiin hankittiin myös taimistoilta samojen lajien kantoja. Mukana oli 54 lajia, lajiketta tai kantaa. Koemenetelmänä olivat pellolle perustetut kenttäkokeet MTT:ssä ja käyttökokeet viherrakentamiskohteissa kaupungeissa.

Kenttäkokeet perustettiin koeruutuihin MTT puutarhatutkimuksen pellolle Piikkiöön ja PohjoisPohjanmaan tutkimusasemalle Ruukkiin käyttäen koeasetelmana epätäydellisten lohkojen mallia. Koejäseninä olivat Piikkiössä kasvikannat, kaksi taimikokoa, kaksi istutustiheyttä ja kaksi valotasoa, Ruukissa vain kasvikannat. Koejärjestelyt on esitetty tarkasti julkaisuissa (Vehkalahti \& Juhanoja 2001, Juhanoja 2005).

Kenttäkokeiden havainnot tehtiin ruutukohtaisesti. Osa ominaisuuksista oli mitattavia, jatkuvia, osa luokittelevia. Koeruuduista tehdyissä havainnoissa keskityttiin kasvuston talvenkestävyyteen, terveyteen ja ulkonäköön sekä peittävyyteen. Lisäksi kasvikannoista tehtiin yksityiskohtaisia kuvailevia havaintoja fenologiasta (lehtien puhkeaminen, kukinnan ajoittuminen, ruskaantumisajankohta) sekä kukinnan runsautta, kukkien ja hedelmien merkitystä sekä muita erityispiirteitä koskevia havaintoja. Kasvustojen levittäytyneisyyttä ja peittävyyttä arvioitiin kasvukausien loppupuolella. Levittäytyneisyys saadaan laskemalla kuinka monessa ruudussa näkyy elävää koekasvin versoa, lehtiä tai kukkia. Saatu luku kuvaa levittäytyneisyyttä prosentteina, ja sitä miten laajalle kasvusto on koeruudussa levittäytynyt. Peittävyys havainnoitiin laskemalla ne havaintoruudut, jotka ovat kokonaan kasvin peittämiä. Saatu luku kuvaa prosentteina sitä, miten suuren osan koeruudusta kasvusto peittää niin täysin, ettei maata näy lainkaan lehtien ja versojen välistä.

Maanpeitekasvien käyttökokeet perustettiin Helsingin, Kuopion, Lahden, Mikkelin, Tampereen ja Turun kaupunkeihin yhteistyössä niiden viheryksiköiden kanssa. Kaupunkien tarjoamien paikkojen joukosta valittiin erityyppisiä kohteita. Koeistutukset perustettiin kunkin kaupungin normaalikäytännön mukaisesti ja kasvualustoina käytettiin niiden omia multaseoksia. Koepaikkojen hoito toteutettiin kaupungeissa niiden tavanmukaisen ohjelman ja resurssien mukaisesti. Näin ollen koepaikkojen olosuhteet poikkesivat toisistaan paitsi sijainniltaan, myös kasvualustan ja hoidon suhteen. Erityisesti kastelukäytännöt vaihtelivat eri kaupungeissa.

Suurin osa koekohteista istutettiin elo-syyskuussa 1998. Yhteensä oli 30-34 koepaikkaa (laskutavasta riippuen) ja niissä 252 erikseen havainnoitavaa istutusryhmää. Vuonna 2001 perustettiin vielä Helsinkiin kolme uutta kohdetta, joihin istutettiin aikaisemmin perustetuissa kokeissa hyviksi osoittautuneita lajeja pieninä kevyttaimina. Kasvit lisättiin MTT puutarhatuotannossa, ja ne istutettiin touko- kesäkuussa 2001. Näissä kohteissa käytettiin katteita. Koekohteet, niiden ominaisuudet, käytetyt lajit ja kohteen tilanne 2003 syksyllä on kuvattu hankkeen loppuraportissa (Juhanoja 2005).

Kaupunkien käyttökokeita käytiin havainnoimassa vähintään kaksi kertaa kasvukauden aikana. Erityistä huomiota kiinnitettiin kasvien helppohoitoisuuteen ja niiden selviytymiseen erilaisten ympäristörasitteiden keskellä. Tällaisia asioita ovat tallaus, aurausvahingot, hiekoitushiekan ja lumen kasautuminen, tiesuola, pakokaasut, rikkakasvit ja mekaaniset kulutusvauriot. Lisäksi tehtiin havaintoja kasvuston yleisulkonäöstä, rikkakasvien määrästä ja lajistosta sekä tautien ja tuholaisten aiheuttamista vaurioista kasveissa. Myös kasvuston korkeus mitattiin ja arvioitiin sanallisesti peittävyys ja levittäytyminen. Lumitilanne käytiin lisäksi tarkistamassa yhtenä runsaslumisena talvena.

Kenttäkokeiden tuloksista peittävyys- ja levittäytyneisyysarvot on laskettu Excel- ja SASohjelmistojen avulla (versio 8.1) ja tulokset on esitetty julkaisuissa (Vehkalahti \& Juhanoja 2001, Juhanoja 2005). Muut havainnot on esitetty kuvailevassa tekstissä samoissa julkaisuissa.

\section{Tulokset ja tulosten tarkastelu FinE $^{\circledR}$-tavaramerkki}

Vuonna 1997 otettiin käyttöön FinE $^{\circledR}$-tavaramerkki. FinE ${ }^{\circledR}$-tavaramerkki voidaan myöntää kasveille, jotka ovat Suomessa tutkittuja, perimältään korkealaatuisia, terveitä, helposti lisättäviä ja Suomen 
oloihin sopivia. Näin ollen tavaramerkki on hyvän kasvimateriaalin laadun tae. Merkki ei silti takaa yksittäisen taimen kasvua, jos sitä ei hoideta asianmukaisesti.

Tavaramerkin ovat kehittäneet MTT ja Taimistoviljelijät ry. Merkin omistaa MTT, ja sen käyttöä valvoo ja ohjaa Taimistoviljelijöiden ja MTT:n edustajista koostuva työryhmä. Työryhmä valitsee kasvit, jotka voivat saada $\mathrm{FinE}^{\mathbb{B}}$-tunnuksen, tekee sopimukset viljelijöiden ja kauppiaiden kanssa, määrittää myytävien kasvien FinE $^{\circledR}$-käyttömaksun ja päättää maksuina kerättyjen varojen käytöstä. FinE ${ }^{\circledR}$-kasvien emotaimia on saatavana MTT:n Laukaan tutkimus- ja valiotaimiasemalta. FinE $^{\circledR}$-tavaramerkin käyttöaluetta laajennetaan vähitellen käsittämään kaikki viherrakentamisessa tarvittavat kasviryhmät.

Tavaramerkin saamisen perusteena ovat joko Suomessa suoritetut vertailevat kokeet tai pitkäaikainen kokemus kasvin ominaisuuksista yhdellä tai useammalla paikalla. Kasvikantojen menestymisseurantaa ja valintaa on tehty pitkään myös kasvitieteellisissä puutarhoissa ja arboretumeissa. Tällä hetkellä FinE ${ }^{\mathbb{B}}$-koristekasveja on 19.

FinE ${ }^{\circledR}$-tavaramerkin käyttöoikeus voidaan myöntää myös hedelmä- ja marjalajikkeille, jotka ovat suomalaisen jalostustyön tuloksia, hyviksi todettuja viljelykantoja tai ulkomaisia meillä menestyviksi todettuja lajikkeita. Marjakasvien taimien tulee olla varmennetun taimituotannon kautta tuotettuja. Tällä hetkellä kotipuutarhoihin soveltuvia FinE ${ }^{\circledR}$-hedelmä- ja marjalajikkeita on 20.

\section{Keskas-kantavalintakokeet}

Kantavalintakokeiden tulosten perusteella osa kannoista nimettiin uudelleen. Syynä tähän oli, että samalla nimellä markkinoidun kasviaineiston ominaisuudet vaihtelivat. Hyväksi todetulle kannalle annettiin tällaisessa tapauksessa eri nimi. Vain osa suositeltavista kannoista on saanut FinE ${ }^{\circledR}$ tavaramerkin käyttöoikeuden. Kaikki suositeltavat kannat ovat lisäyksessä ja emokasvituotannossa Laukaan tutkimus- ja valiotaimiasemalla.

Kantavalintakokeiden tulosten perusteella tähän mennessä 15 koristepensasta on saanut FinE ${ }^{\circledR}$ tavaramerkin käyttöoikeuden:

Syyshortensia Hydrangea paniculata 'Grandiflora'

Mustilanhortensia Hydrangea paniculata 'Mustila'

Kuutamohortensia Hydrangea paniculata 'Praecox'

Huntukuusama Lonicera $\times$ bella 'Dropmore'

Sirokuusama Lonicera $\times$ bella 'Sakura'

Loistojasmike Philadelphus Lewisii -ryhmä 'Tähtisilmä'

Hovijasmike Philadelphus pubescens 'Tuomas'

Morsionruusu Rosa Pimpinellifolia -ryhmä 'Juhannusmorsian'

Juhannusruusu Rosa pimpinellifolia 'Plena'

Suviruusu Rosa Pimpinellifolia -ryhmä 'Poppius'

Valkopajuangervo Spiraea alba 'Allikko'

Verhoangervo Spiraea beauverdiana 'Lumikki'

Kiiminginangervo Spiraea Chamaedryfolia-ryhmä 'Martti'

Kuninkaanangervo Spiraea $\times$ watsoniana 'Kruunu'

Lumipalloheisi Viburnum opulus 'Pohjan Neito'.

Kaksi lajia on saanut käyttöoikeuden pitkäaikaisen, eri menestymisvyöhykkeiltä saadun

kokemuksen perusteella:

Höyhenpensas Fothergilla major 'Velho'

Kevätatsalea Rhododendron $\times$ fraseri .

\section{Puuvartiset maanpeitekasvit}

Lajien peittävyys- ja levittäytymisominaisuuksien perusteella parhaiten peittopensaiksi soveltuvat lajit voidaan ryhmitellä kolmeen erilaiseen tyyppiin, joille voidaan antaa suositukset käytettävää taimikokoa ja kasvuston perustamistapaa varten.

\section{Nopeasti levittäytyvä, ei täydellisesti peittävä tyyppi}

Nämä pensaat ovat usein luonnossa pioneerilajeja, niukasti tai ei lainkaan juurivesoja ja rönsyjä kasvattavia, pienilehtisiä pensaita, jotka levittäytyvät nopeasti pitkiä versoja kasvattamalla. Versot eivät yleensä juurru kasvualustaan. Pienen lehtikoon tai pystyn lehtiasennon vuoksi lajit eivät peitä alustaa täysin, vaan valo pääsee kasvuston läpi. Yleisvaikutelma maisemassa on kuitenkin vihreän 
mattomainen ja yhtenäinen. Kasvusto voidaan perustaa lajista riippuen istuttamalla joko kevyttaimia tiheään (taimiväli 20-30 cm; vähintään $7 \mathrm{kpl}$ neliömetrille) tai astiataimia harvempaan (taimiväli noin $70 \mathrm{~cm}$; noin $3 \mathrm{kpl}$ neliömetrille). Istutuksissa on syytä käyttää katekangasta, joka voidaan vielä peittää sepelillä tai hakkeella. Kokeissa mukana olleista suositeltavista lajeista tähän ryhmään kuuluvat lamohietakirsikka Prunus pumila var. depressa, pikkuherukka Ribes glandulosum, peittopaju Salix $\times$ aurora ja paljakkapaju S.glauca var. callicarpaea.

\section{Nopeasti levittäytyvä, kohtalaisesti tai hyvin peittävä tyyppi}

Nämä lajit ovat hyvin pitkiä versoja kasvattavia, nopeasti ja aggressiivisesti levittäytyviä. Versot myös juurtuvat kasvualustaan ja lajit muodostavat rönsyjä. Kasvustosta tulee nopeasti peittävän näköinen, ja se myös on käytännössä lähes täysin peittävä. Istutusryhmä voidaan perustaa joko istuttamalla katekankaan läpi tai ilman katekangasta; kasvualustan pinnalle levitettävä hake tai sepeli parantaa ryhmän ulkonäköä etenkin nuorissa kasvustoissa ja keväällä ennen uusien versojen kasvua. Istutuksiin voidaan käyttää astiataimia tai pienempiä kevyttaimia, joita istutetaan tiheämpään. Suositeltavista lajeista tätä tyyppiä edustavat vatukoihin kuuluvat lajit sinivatukka Rubus caesius ja kiiltovatukka R.crataegifolius 'Prelude'.

\section{Melko nopeasti levittäytyvä, lähes täydellisesti peittävä tyyppi}

Nämä lajit ovat kasvumuodoltaan tiiviitä pikkupensaita, joiden levittäytyminen sivusuunnassa on lähinnä pensaan kasvua ja rehevöitymistä, osa lajeista kasvattaa lisäksi juurivesoja. Kasvusto on niin tiheä, että riittävän tiheään istutetut taimet peittävät kasvualustan täydellisesti. Istutusryhmä voidaan perustaa ilman katekangasta, ja tämä on suositeltavaakin lajeille, jotka kasvattavat juurivesoja. Haketai sepelikerros kasvualustan pinnalla on eduksi istutuksen jälkeen. Näiden lajien istutuksiin on syytä käyttää astiataimia, joiden kasvuunlähtö on nopeampi. Suositeltavista lajeista tätä tyyppiä edustavat vuohenkuusamat Diervilla-suku, hanhikit Dasiphora, Pavement-ruusut Rosa 'Foxi Pavement' ja 'Pink Pavement', pensasangervot Spiraea, seppelvarpu Stephanandra incisa ja valkolumimarjapensas Symphoricarpos 'Arvid'.

Tähän mennessä kaksi peittopensasta on saanut FinE $^{\circledR}$-tavaramerkin käyttöoikeuden:

Peittopaju Salix $\times$ aurora 'Tuhkimo'

Paljakkapaju Salix glauca var. callicarpaea 'Haltia'

\section{Johtopäätökset}

Keskas-kantavalintakokeiden ja maanpeitekasvien kenttä- ja käyttökokeiden tulosten perusteella kasvimateriaalin laadun parantamiseksi ja kasvien käyttösuositusten laatimiseksi tarvitaan laajamittaisia kokeita. Yhtenäisissä pelto-olosuhteissa kasvatettaessa kasvilajien ja -kantojen ulkoiset ominaisuudet ja kestävyys sekä kantojen väliset erot näissä ominaisuuksissa saadaan näkyviin. Tämä on riittävä tulos silloin kun ei erityisesti etsitä kasveja tiettyihin erityistarkoituksiin, vaan kantojen välisiä eroavaisuuksia. Kenttäkokeiden keston pitää kuitenkin olla riittävä, puuvartisilla kasveilla vähintään 5 vuotta, yksilö- ja toistomäärän riittävä ja koepaikkojen ilmastollisesti toisistaan poikkeavia. Koepaikkoja tarvitaan vähintään 2-3. Kenttäkokeiden laajuutta vertailevissa kokeissa voitaisiin huomattavasti pienentää, mikäli identtiset kannat voitaisiin selvittää aineistosta ennen kenttäkokeita DNA-tunnistuksen avulla, ja vain toisistaan poikkeavat kannat ottaa mukaan perustettaviin kenttäkokeisiin. Tilastollisia ja ei-tilastollisia menetelmiä yhdistämällä pystytään kasvien valinnassa hyödyntämään hyvin erityyppisiä ominaisuuksia, esim. luokittelevalla asteikolla arvosteltavia ja selvästi mitattavia ja sulkemaan pois arvostelijan henkilökohtainen mielipide.

Vertailevista kenttäkokeista saadaan näkyviin kantojen perusominaisuuksia, mutta kasvien soveltuvuudesta erilaisiin kohteisiin ja käyttötarkoituksiin voidaan tehdä päätelmiä vain ko. kasvien kasvutavan, leviämiskyvyn ym. perusteella. Avoin peltoympäristö ei ole kaikille lajeille sovelias kasvu- ja koepaikka. Käyttökokeista todellisissa viherrakentamiskohteissa saadaan tärkeätä tietoa kasvien kyvystä sietää kuivuutta, seisovaa märkyyttä, aurausta, lumen painoa, tiesuolaa, tallausta, puiden varjoa, paahdetta, tuulta, liikenteen aiheuttamaa ilmavirtaa ym. Käyttökokeissa on mahdollista löytää kasvien selviytymisen äärirajoja eikä ylihoitamisen vaaraa ole niin kuin kenttäkokeissa, joissa jotkut kasvit voivat kasvaa liian hyvissä olosuhteissa. Käyttökokeista saatava tieto on oleellista erityisesti ongelmakohteisiin kasveja valittaessa. Jos toisaalta tehtäisiin kasveilla pelkkiä käyttökokeita, jäisi tieto kasvin koko-, kukinta-, leviämiskyky- ym. ja ympäristörasitteiden sietorajoista puutteelliseksi. Myös riskit koekasvien tuhoutumiselle ovat käyttökokeissa todellisia. 
Käyttökokeissa perustamis- ja hoitotoimenpiteet ovat ko. alueella yleisesti käytössä olevien käytäntöjen mukaiset, jolloin vaihtelu voi olla suurta esim. eri kaupunkien kesken. Toisaalta tämä tarjoaa mahdollisuuden kerätä tietoa kasvien menestymisestä erilaisessa hoitokulttuurissa. Kenttäkokeet ja käyttökokeet täydentävät toisiaan, ja kenttäkokeiden ja käyttökokeiden yhdistäminen on paras tapa saada tietoa kasvien soveltumisesta erilaisiin olosuhteisiin.

\section{Kirjallisuusluettelo}

Alanko, P. \& Tegel, S. 1989. KESKAS-tutkimus. Kestäviä koristekasveja viherrakentamisen tarpeisiin. SITRA Sarja B nro 98. 11 p. Kyriiri Oy, Helsinki. ISBN 951-563-219-6.

Juhanoja, S. 2005. Puuvartisia peittokasveja. Loppuraportti tutkimushankkeesta "Puuvartisten maanpeitekasvien menestyminen ja soveltuminen eri käyttökohteisiin" vuosilta 1998-2003. 49 p. Available at MTT Kasvintuotannon tutkimus, puutarhatuotanto, Toivonlinnantie 518, 21500 Piikkiö. ISBN 951-729-945-1.

-, Heikkilä, M. \& Virtanen, A. 1998. Clone selection of woody ornamentals in Finland. Acta Agriculturae Scandinavica, Section B, Soil and Plant Science 48: 113-127.

-, Aaltonen, M., Aflatuni, A., Heinonen, A., Kemppainen, R., Paasikivi, P., Sorvari, K. Vehkalahti, M. \& Virtanen, A. 2001. Tutkittuja kasveja viherrakentamisen tarpeisiin. KESKAS-kantavalintakokeet MTT:ssä vuosina 1988-2000. MTT:n julkaisuja sarja A 98: 1-60, 11 liitettä. ISBN 951-729-622-3. ISSN 1239-0852.

Vehkalahti, M. \& Juhanoja, S. 2001. Peittokasveja kaupunkiympäristöihin. Raportti tutkimuksesta 'Puuvartisten maanpeitekasvien menestyminen ja soveltuminen eri käyttökohteisiin' vuosilta 1998-2000. 60 p. Available at MTT Kasvintuotannon tutkimus, puutarhatuotanto, Toivonlinnantie 518, 21500 Piikkiö. ISBN $951-$ 729-606-1 